\title{
Paparan Debu Batubara Subkronik pada Peroksidasi Lipid dan Kadar Gula Darah Tikus Diabetes Melitus
}

\author{
Agus Yuwono, ${ }^{1}$ Bambang Setiawan, ${ }^{2}$ Nia Kania, ${ }^{3}$ Nurdiana, ${ }^{4}$ M. Aris Widodo ${ }^{4}$ \\ ${ }^{1}$ Bagian Ilmu Penyakit Dalam, ${ }^{2}$ Bagian Kimia Kedokteran, ${ }^{3}$ Bagian Patologi Anatomi \\ RSUD Ulin Banjarmasin, Fakultas Kedokteran Universitas Lambung Mangkurat Banjarbaru \\ ${ }^{4}$ Bagian Farmakologi, Fakultas Kedokteran Universitas Brawijaya Malang
}

\begin{abstract}
Abstrak
Di Kalimantan Selatan, prevalensi penderita diabetes melitus sebesar 11,1\%. Kalimantan Selatan merupakan provinsi dengan tambang batubara tersebar di seluruh wilayah. Hal ini menjadikan penderita diabetes melitus terpapar debu batubara. Penelitian ini bertujuan untuk mengukur peroksidasi lipid akibat paparan debu batubara subkronik dan pengaruhnya pada kadar gula darah tikus diabetes melitus. Kelompok penelitian meliputi tikus Wistar diabetes melitus (P1), kelompok diabetes melitus + paparan debu batubara dosis $12,5 \mathrm{mg} / \mathrm{m}^{3} 1 \mathrm{jam} / \mathrm{hari}$ selama 28 hari (P2), dan kelompok diabetes melitus + paparan debu batubara dosis $25 \mathrm{mg} / \mathrm{m}^{3} 1$ jam/hari selama 28 hari (P3), masing-masing 6 ekor. Penelitian dilakukan mulai Agustus-Oktober 2010. Uji analysis of variance (ANOVA) terhadap kadar malondialdehid (MDA) plasma tidak didapatkan peningkatan secara bermakna antara kelompok perlakuan ( $\mathrm{p}>0,05)$. Penurunan kadar gula untuk P1, P2, dan P3 berturut-turut sebesar 23,6\%, 16,9\%, dan 9,3\%. Analisis uji t tidak berpasangan terhadap kadar gula darah tidak didapatkan perbedaan bermakna sebelum dan setelah perlakuan pada semua kelompok $(\mathrm{p}>0,05)$. Tidak terdapat korelasi antara kadar MDA plasma dan kadar gula darah setelah perlakuan pada berbagai kelompok $(\mathrm{p}>0,05)$. Disimpulkan bahwa paparan debu batubara subkronik tidak meningkatkan peroksidasi lipid yang mempengaruhi kadar gula darah pada tikus diabetes melitus dan tidak ada korelasi antara kadar MDA dan glukosa darah. [MKB. 2011;43(4):189-92].
\end{abstract}

Kata kunci: Debu batubara, diabetes melitus, hiperglikemia, peroksidasi lipid

\section{Subchronic Coal Dust Exposure on Lipid Peroxidation and Blood Glucose Level in Diabetes Mellitus Rat}

\begin{abstract}
In South Kalimantan, prevalence of diabetes mellitus was $11.1 \%$. South Kalimantan is a province with coal mine spread in all districts. This condition induce coal dust exposure on diabetes mellitus patients. Aim of this study was to measure lipid peroxidation by subchronic coal dust exposure and its effect on glucose level in Wistar rats model of diabetes mellitus. Group included diabetes mellitus Wistar rats (P1), diabetes mellitus + coal dust exposure at dose $12.5 \mathrm{mg} / \mathrm{m}^{3} 1$ hour/day for 28 days (P2) and diabetes mellitus + coal dust exposure at dose $25 \mathrm{mg} / \mathrm{m}^{3} 1$ hour/day for 28 days (P3) on 6 rats, respectively. This research was done from August-October 2010. Analysis of variance (ANOVA) test concluded no significant differently on increased plasma malondialdehyde (MDA) level between all groups $(\mathrm{p}>0.05)$. Percentage of blood glucose level decreased $23.6 \%, 16.9 \%$ and $9.3 \%$ for P1, P2, P3 group, respectively. Unpaired t test concluded that blood glucose level were not significant differently between pre and post treatment in all groups $(\mathrm{p}>0.05)$. There was no correlation between plasma MDA level and blood glucose level in all groups of exposure $(\mathrm{p}>0.05)$. In conclusions, that subchronic coal dust exposure doesn't increase lipid peroxidation and no effect on blood glucose level in diabetes mellitus rats and no correlation between MDA dan blood glucose level. [MKB. 2011;43(4):189-92].
\end{abstract}

Key words: Coal dust, diabetes mellitus, hyperglycemia, lipid peroxidation

Korespondensi: Agus Yuwono, dr., SpPD, Bagian Ilmu Penyakit Dalam RSUD Ulin Banjarmasin, jalan Ahmad Yani Km 2, Banjarmasin, Kalimantan Selatan, mobile 0811502053, e-mail agsyuwono@gmail.com 


\section{Pendahuluan}

Diabetes melitus (DM) merupakan kelainan metabolisme karbohidrat yang ditandai oleh hiperglikemia kronik yang disebabkan oleh kekurangan insulin secara relatif maupun absolut. Hiperglikemia serta kelainan metabolik lainnya didasari oleh berkurangnya produksi hormon insulin oleh sel beta pankreas yang disebabkan oleh berbagai proses. ${ }^{1}$ Di Kalimantan Selatan, prevalensi penderita diabetes melitus diperkirakan sebesar 11,1\%. ${ }^{2}$ Kalimantan Selatan juga merupakan daerah tambang batubara terbesar dengan lokasi yang tersebar di seluruh wilayah. ${ }^{3}$ Hal ini menjadikan penderita diabetes melitus di Kalimantan Selatan potensial untuk terpapar debu batubara.

Peroksidasi lipid merupakan proses yang bersifat kompleksakibatreaksiasam lemak tidakjenuh ganda penyusun fosfolipid membran sel dengan senyawa oksigen reaktif membentuk hidroperoksida. ${ }^{4}$ Senyawa oksigen reaktif merupakan senyawa turunan oksigen yang lebih reaktif dibandingkan dengan oksigen pada kondisi dasar (ground state). ${ }^{5}$ Peroksidasi lipid merupakan marker stres oksidatif. Peroksidasi lipid akibat paparan debu batubara telah diungkap pada berbagai penelitian. Penelitian Pinho dkk. $^{6}$ didapatkan peningkatan pembentukan thiobarbituric acid reactive substance (TBARS) pada paru tikus yang diberikan debu batubara melalui instilasi intratrakea. Penelitian Armutcu dkk. ${ }^{7}$ juga didapatkan peningkatan kadar malondialdehid (MDA) paru dan plasma pada tikus yang terpapar debu batubara di tambang bawah tanah selama 1,2, dan 4 minggu.

Pada tikus model diabetes melitus, mekanisme streptozotocin (STZ) dalam memicu hiperglikemia disebabkan oleh terjadinya apoptosis sel beta pankreas, meskipun jalur yang terlibat belum dapat dimengerti sepenuhnya. Menurut Pisarev dkk. ${ }^{8}$ mekanisme kerusakan sel beta pankreas disebabkan oleh kegagalan penggunaan glukosa karena terdapatnya alkilasi protein untuk uptake dan metabolisme glukosa dan kerusakan mitokondria, sehingga terjadi stres oksidatif serta kerusakan deoxyribo nucleic acid (DNA). Mekanisme lain terjadi melalui efek stres oksidatif. Streptozotocin akan melepaskan nitrit oksida (NO) dan radikal hidroksil $(\bullet \mathrm{OH})$ dalam jumlah besar. Radikal tersebut akan mengoksidasi protein sitosol, sehingga mengubah struktur protein yang selanjutnya dikenal sebagai neoantigen. Neoantigen akan dipresentasikan oleh molekul major histocompatibility complex-1 (MHC-1) dan dikenal oleh sel T sitotoksik. Sel T sitotoksik akan menghasilkan perforin, granzim, dan Fas ligand untuk memicu sinyal apoptosis. ${ }^{9}$

Malondialdehid merupakan marker stres oksidatif akibat peroksidasi lipid. Malondialdehid berada dalam berbagai bentuk bergantung pada $\mathrm{pH}$. Pada $\mathrm{pH}$ fisiologis, MDA bebas akan berada dalam bentuk ion enolat yang mempunyai reaktivitas rendah terhadap gugus asam amino. Apabila $\mathrm{pH}$ menurun, reaktivitasnya akan meningkat. Pada $\mathrm{pH}$ fisiologis, protein lebih peka untuk diserang oleh MDA dibandingkan dengan gugus asam amino. Hal ini akan memicu modifikasi protein yang akan dikenali sebagai neoantigen. ${ }^{10}$ Dengan demikian, diduga terdapat hubungan antara peningkatan MDA akibat paparan debu batubara dan peningkatan apoptosis pankreas yang ditandai oleh peningkatan kadar glukosa darah.

Tujuan penelitian untuk mengukur peroksida lipid akibat paparan debu batubara subkronik dan pengaruhnya pada kadar gula darah tikus diabetes melitus, juga hubungan antara kadar malondialdehid dan kadar gula darah.

\section{Metode}

Penelitian ini merupakan penelitian eksperimetal. Subjek penelitian ini berupa tikus Wistar jantan dengan bobot 200-250 gram yang diperoleh dari Laboratorium Farmakologi Fakultas Kedokteran Universitas Brawijaya Malang. Kelompok pada penelitian ini dibedakan atas kelompok diabetes melitus (P1), kelompok diabetes melitus + paparan debu batubara dosis $12,5 \mathrm{mg} / \mathrm{m}^{3} 1 \mathrm{jam} /$ hari selama 28 hari (P2); dan kelompok diabetes melitus + paparan debu batubara dosis $25 \mathrm{mg} /$ $\mathrm{m}^{3} 1$ jam/hari selama 28 hari (P3). Paparan 28 hari merupakan paparan subkronik. Jumlah tikus setiap kelompok sebanyak 6 ekor tikus. Penelitian ini terbagi atas tiga tahap, yakni pembuatan dan analisis anorganik debu batubara, pembuatan tikus diabetes melitus, pemaparan, serta pemeriksaan parameter. Penelitian dilakukan mulai AgustusOktober 2010.

Pembuatan debu batubara dimulai dengan menghancurkan batubara dengan menggunakan pulverizer yang terdiri atas Ball mill, Ring mill, dan Raymond mill di Carsurin Coal Laboratories Banjarmasin. Pulverizer akan menghasilkan debu batubara diameter $<70 \mu \mathrm{m}$. Penyaringan dengan mesh microSieve (BioDesign, United State of America) akan didapatkan debu batubara diameter $<10 \mu \mathrm{m}$. Debu diameter $<10 \mu \mathrm{m}$ bersifat respirable particulate matter. Diameter debu batubara $<10 \mu \mathrm{m}$ yang digunakan pada penelitian ini lebih kecil daripada diameter debu batubara penelitian Pinho dkk. ${ }^{6}(<15 \mu \mathrm{m})$ akan tetapi lebih besar dibandingkan dengan penelitian Ghanem dkk. ${ }^{11}(3,4 \mu \mathrm{m})$ dan Armutcu dkk. ${ }^{7}(0,5-5 \mu \mathrm{m})$. Selanjutnya, debu batubara akan dianalisis 
kandungan anorganik dengan $X$-ray fluorescence di Laboratorium Sentral Universitas Negeri Malang.

Pembuatan tikus diabetes melitus dilakukan dengan merusak pankreas melalui pemberian STZ. Urutan kerjanya menimbang berat badan dan mengukur kadar glukosa darahnya; melarutkan STZ pada bufer sitrat $0,1 \mathrm{M}$ sehingga $\mathrm{pH}$ larutan menjadi 4,5; menyuntikkan STZ pada tikus secara intravena dosis $55 \mathrm{mg} / \mathrm{kgBB}$; dan tiga hari kemudian dilakukan pengukuran kadar glukosa darah ekor dengan gluco test. Tikus yang menjadi diabetes melitus $(\geq 160 \mathrm{mg})$ akan digunakan dalam penelitian. ${ }^{12}$

Pemaparan debu batubara menggunakan alat coal dust exposure model 2010 yang didesain dan tersedia di Laboratorium Farmakologi Fakultas Kedokteran Universitas Brawijaya Malang. Prinsip alat tersebut untuk menyediakan lingkungan ambien debu batubara yang dapat terinhalasi ke dalam saluran napas. Dosis paparan debu batubara mengikuti penelitian sebelumnya, yaitu dosis tinggi sebesar $12,5 \mathrm{mg} / \mathrm{m}^{3} .^{11}$ Lama paparan per hari selama 1 jam.

Pembedahan dilakukan setelah pemaparan 28 hari dengan eter sebagai bahan anestesi. Pembedahan dilakukan pada tikus yang masih mempunyai detak jantung dengan membuka abdomen, memotong kosta, dan membuka rongga dada untuk menemukan jantung. Darah yang diperoleh dari jantung digunakan untuk pemeriksaan kadar MDA plasma yang dilakukan di Laboratorium Farmakologi Fakultas Kedokteran Universitas Brawijaya Malang. Selain itu, juga diukur kadar gula darah sebelum dan setelah perlakuan paparan debu batubara. Kadar gula darah diukur pada ekor tikus dengan alat gluco test.

Data yang diperoleh dianalisis dengan uji statistik menguji perbedaan kadar MDA berbagai kelompok akan dianalisis dengan uji analysis of variance (ANOVA). Kadar gula darah sebelum dan setelah perlakuan dengan uji t tidak berpasangan. Selain itu juga dilakukan uji korelasi antara kadar MDA dan kadar gula darah setelah perlakuan. Perbedaan disimpulkan bermakna apabila nilai $\mathrm{p}<0,05$. Uji statistik dengan program SPSS for windows versi 12.

\section{Hasil}

Analisis anorganik kandungan debu batubara didapatkan berbagai mineral Fe 36,9\%; Si 17,9\%; Mo $15 \%$; Al 10\%; Ca 8,67\%; S 4,7\%; Ti 3,65\%. Beberapa mineral terdapat dalam kandungan di bawah $<1 \%$ meliputi $\mathrm{K}, \mathrm{V}, \mathrm{Cr}, \mathrm{Mn}, \mathrm{Ni}, \mathrm{Cu}$, dan Yb. Kadar MDA plasma pada berbagai kelompok perlakuan cenderung mengalami peningkatan. Uji ANOVA terhadap kadar MDA plasma tidak didapatkan peningkatan secara bermakna antara kelompok perlakuan $(\mathrm{p}>0,05)$.

Kadar glukosa darah sebelum dan setelah paparan debu batubara cenderung mengalami penurunan. Semakin besar dosis paparan debu batubara, maka semakin besar persentase penurunan kadar gula darah. Penurunan kadar gula untuk P1, P2, dan P3 masing-masing 23,6\%, $16,9 \%$, dan $9,3 \%$. Analisis uji t tidak berpasangan terhadap kadar gula darah tidak didapatkan perbedaan bermakna sebelum dan setelah perlakukan pada semua kelompok $(\mathrm{p}>0,05)$. Selain itu, juga tidak terdapat korelasi antara kadar MDA plasma dan kadar gula darah setelah perlakuan pada berbagai kelompok $(\mathrm{p}>0,05)$.

\section{Pembahasan}

Pada penelitian ini selain didapatkan kandungan mineral anorganik dari debu batubara, seperti terlihat pada hasil, juga terdapat beberapa mineral dengan kadar di bawah $<1 \%$ di antaranya $\mathrm{K}, \mathrm{V}, \mathrm{Cr}, \mathrm{Mn}, \mathrm{Ni}, \mathrm{Cu}$, dan Yb. Berbagai peneliti menyatakan bahwa Fe sebagai bahan aktif dari debu batubara yang memicu peroksidasi lipid, ${ }^{13,14}$ meskipun dapat juga terjadi akibat mineral lain, misalnya Ti, V, Cr, dan $\mathrm{Mn}^{10}$

Besi merupakan katalis peroksidasi lipid yang bersifat merusak. Besi dapat memicu dan memperkuat peroksidasi lipid. Tahap inisiasi dapat dipicu oleh dua mekanisme yang melibatkan radikal hidroksil dan tanpa radikal hidroksil. Pada mekanisme yang melibatkan radikal hidroksil, peroksidasi lipid dipicu oleh radikal hidroksil pada reaksi Fenton dengan besi sebagai reaktan. Pada mekanisme tidak bergantung pada radikal hidroksil, peroksidasi lipid dipicu oleh kompleks

Tabel Kadar Gula Darah dan Kadar MDA Tikus Diabetes Melitus

\begin{tabular}{lcccccccccc}
\hline & \multicolumn{3}{c}{ P1 } & \multicolumn{1}{c}{ P2 } & \multicolumn{3}{c}{ P3 } \\
\cline { 2 - 11 } & Sebelum & Setelah & $\begin{array}{c}\text { Penu- } \\
\text { runan } \\
(\mathbf{\%})\end{array}$ & Sebelum & Setelah & $\begin{array}{c}\text { Penu- } \\
\text { runan } \\
(\mathbf{\%})\end{array}$ & Sebelum & Setelah & $\begin{array}{c}\text { Penu- } \\
\text { runan } \\
(\%)\end{array}$ \\
\hline GDS & 353,4 & 269,9 & 23,6 & 386 & 320,6 & 16,9 & 420,7 & 381,5 & 9,3 \\
MDA & - & 0,8044 & - & - & 0,8675 & - & - & 0,9399 & - \\
\hline
\end{tabular}


besi-oksigen, berupa ion perferil dan feril. ${ }^{15}$

Pada penelitian ini tidak terbukti bahwa paparan debu batubara menyebabkan peningkatan kadar MDA secara bermakna. Hal ini disebabkan mekanisme terminasi yang berlangsung apabila radikal bebas bertemu dengan radikal bebas membentuk senyawa kompleks netral. Di satu sisi radikal bebas akan dibentuk dari paparan debu batubara dan di sisi lain radikal bebas akan dibentuk akibat hiperglikemia. Apabila keduanya bertemu, maka tidak memicu peroksidasi lipid sebagai marker stres oksidatif. Hasil penelitian ini berbeda dengan penelitian Armutcu dkk. ${ }^{7}$ yang mendapatkan peningkatan kadar MDA plasma pada paparan tambang bawah. Perbedaan ini diduga disebabkan oleh lama waktu paparan setiap hari, untuk penelitian ini 1 jam per hari sedangkan Armutcu dkk. ${ }^{7}$ selama 24 jam per hari.

Selanjutnya, peroksidasi lipid akibat paparan debu batubara tidak berkorelasi dengan kadar gula darah. Hal ini mengindikasikan bahwa peroksidasi lipid tidak meningkatkan pembentukan neoantigen di pankreas yang dapat memicu apoptosis pankreas lebih lanjut. Disimpulkan bahwa paparan debu batubara subkronik tidak meningkatkan peroksidasi lipid yang mempengaruhi kadar gula darah pada tikus diabetes melitus.

\section{Daftar Pustaka}

1. ADA (American Diabetes Association). Report of the expert committee on diagnosis and classification of diabetes mellitus. Virginia: Clinical Practice Recommendation; 2000

2. RISKESDAS. Prevalensi diabetes di Kalimantan Selatan. Jakarta: Badan Penelitian dan Pengembangan Kesehatan; 2009.

3. Furqan EBM. Fenomena pertambangan batubara di Kalimantan Selatan: kebijakan kuras habis dan berorientasi pasar. Tersedia dari: http:www.walhi.or.id; 2007.

4. Robles R, Palomino N, Robles A. Oxidative stress in the neonate. Early Human Dev. 2001;65:575-81.

5. Halliwell B, Whiteman M. Measuring reactive species and oxidative damage in vivo and in cell culture: how should you do it and what do the results mean?. Br J Pharmacol. 2004;142:231-55.

6. Pinho RA, Silveira PCL, Silva LA, Steck EL, Dal-Pizzol F, Moreira JCF. N-acetylsisteine and deferoxamine reduce pulmonary oxidative stress and inflammation in rats after coal dust exposure. Environ Res. 2005; 99:355-60.

7. Armutcu F, Gun BD, Altin R, Gurel A. Examination of lung toxicity, oxidant/ antioxidant status and effect of erdosteine in rats kept in coal mine ambience. Environ Toxicol Pharmacol. 2007;24:106-13.

8. Pisarev VB, Snigur GL, Spasov AA, Samokhina MP, Bulanov AE. Mechanisms of toxic effect of streptozotocin on $\beta$-cells in the islets of Langerhans. Bull Exp Biol Med. 2009;148(6):937-9.

9. Hui H, Dotta F, Di Mario U, Perfetti R. Role of caspases in the regulation of apoptotic pancreatic islet beta cell death. J Cell Physiol. 2004;200(2):177-200.

10. Marjani A. Lipid peroxidation alterations in type 2 diabetic patients. Pak J Bio Sci. 2010; 13(15):723-30.

11. Ghanem MM, Porter D, Batteli LA, Valyathan V, Kashon ML, Ma JY, dkk. Respirable coal dust particle modify cytochrome P4501A1 expression in rat alveolar cells. Am J Respir Cell Mol Biol. 2004;31:171-87.

12. Sivajothi V, Dey A, Jayakar B, Rajkaapor B. Antihyperglicemic propertoes of Thagia cannabina in streptozotocin induced diabetic rats. J Med Food. 2007;10(2):361-5.

13. Zhang Q, Dai J, Ali A, Chen L, Huang X. Roles of bioavailable iron and calcium in coal dust-induced oxidative stress: possible implications in coal workers' lung disease. Free Rad Res. 2002;36:285-94.

14. Huang $\mathrm{X}, \mathrm{Li} \mathrm{W}$, Attfield MD, Nadas A, Frenkel K, Finkelman RB. Mapping and prediction of coal workers' pneumoconiosis with bioavailable iron content in the bituminous coals. Environ Hlth Perspect. 2005;113:964-8.

15. Toxqui L, De Piero A, Cortuis V, Bastida S, Sanchez-Muniz FJ, Vaquero MP. Iron deficiency and overload: implication in oxidative stress and cardiovascular health. Nutr Hosp. 2010;25(3):350-65. 